\title{
The Rule of Law in the International Monetary Fund: Past, Present and Future
}

\author{
Yan Liu*
}

\begin{abstract}
The International Monetary Fund (the "Fund") has evolved considerably since 1945 to respond to the changes in the global economy with its constant mandate to maintain and safeguard a stable international monetary system. Throughout its evolution, the Fund continues to adhere to the rule of law, which is key to the legitimacy, credibility and effectiveness of the Fund as an institution. The Legal Department of the Fund plays a critical role in ensuring that the Fund effectively responds to the changing developments in the international monetary and financial systems while maintaining the rule of law. The responsibilities of legal counsels at the Fund have been expanding over the years to keep up with the Fund's evolution, ranging from traditional in-house counselors, trusted advisors to membership to active public policy contributors. In discharging these responsibilities, legal counsels must maintain independence, objectivity and consistency to ensure credibility and effectiveness of their legal advice, which is pertinent to upholding the rule of law at the Fund.
\end{abstract}

\section{Introduction}

The International Monetary Fund (the "Fund") has evolved since 1945 with developments in the global economy. While its overall objective remains the promotion of international monetary and financial stability, the Fund has adapted its role and policies to respond to the changing developments in the

* Assistant General Counsel of the Legal Department, International Monetary Fund. Email: YLiu@IMF.org. The views expressed in this paper are those of the author and do not necessarily represent the views of the IMF, its Executive Board, or IMF management. The author would like to thank Kyung Kwak for her valuable inputs and comments on this article. 
international monetary and financial systems over the years. ${ }^{1}$ These changes have taken place gradually, but more recently, they were accelerated by several regional and global financial crises where the Fund provided a large amount of financing to members facing acute balance of payments difficulties, and reformed its policies to better prevent and resolve crises. The role of legal counsels at the Fund has also been changing and expanding over the past 70 years to keep up with the Fund's evolution. They not only provide advice on the law of the Fund but also assist member countries in designing and building effective and accountable institutions to support economic stability and growth.

Throughout its evolution, one thing remains unchanged at the Fund, that is, the institution continues to adhere to the rule of law. The rule of law is key to the legitimacy, credibility and effectiveness of the Fund as an institution, and plays a key role in promoting sustainable and equitable growth and financial stability. The Fund is an international organization established by an international treaty, the Articles of Agreement. While the Articles of Agreement are sufficiently flexible to respond to changes in the global economy, they have been amended seven times to implement major policy reforms. This reflects the recognition by the Fund and its membership that there are limitations to the adoption of reforms through interpretation of the Articles and is an important indicator of the acceptance of the rule of law at the Fund.

1 The purposes of the Fund are listed in the Articles of Agreement, Article I:

The purposes of the International Monetary Fund are:

(i) To promote international monetary cooperation through a permanent institution which provides the machinery for consultation and collaboration on international monetary problems.

(ii) To facilitate the expansion and balanced growth of international trade, and to contribute thereby to the promotion and maintenance of high levels of employment and real income and to the development of the productive resources of all members as primary objectives of economic policy.

(iii) To promote exchange stability, to maintain orderly exchange arrangements among members, and to avoid competitive exchange depreciation.

(iv) To assist in the establishment of a multilateral system of payments in respect of current transactions between members and in the elimination of foreign exchange restrictions which hamper the growth of world trade.

(v) To give confidence to members by making the general resources of the Fund temporarily available to them under adequate safeguards, thus providing them with opportunity to correct maladjustments in their balance of payments without resorting to measures destructive of national or international prosperity.

(vi) In accordance with the above, to shorten the duration and lessen the degree of disequilibrium in the international balances of payments of members.

The Fund shall be guided in all its policies and decisions by the purposes set forth in this Article. 
The Legal Department of the Fund plays a critical role in ensuring the Fund's adherence to the rule of law. Its independence, consistency and continuity are particularly pertinent to upholding the rule of law at the Fund. Since there is no mandatory form of judicial review of the Fund's decisions, legal counsels play an important role in advising the Fund's decision-making organs on the consistency of their decisions with the Articles of Agreement and other applicable rules and regulations, and on the consistency of Fund members' actions with their obligations under the Articles. This chapter will focus on three important roles of legal counsels at the Fund: in house counselors, trusted advisors to membership and public policy contributors. It first provides an overview of the Fund's governance structure and key functions which have been shaping those roles. It then turns to the roles of the legal counsels, illustrating their expanded roles in response to the evolution of the Fund over the years. The chapter then discusses the key ingredients for making legal counsels and the Legal Department effective in maintaining the rule of law at the Fund.

\section{Fund's Governance Structure}

The Fund's governance structure consists of the Board of Governors, the Executive Board, and the Managing Director. The Board of Governors is the highest decision-making organ of the Fund. It consists of one governor (and one alternate governor) for each member country who is usually the member's Central Bank Governor or Finance Minister appointed in accordance with national procedures. All powers of the Fund are vested in the Board of Governors, ${ }^{2}$ but it can delegate to the Executive Board all except certain reserved powers. ${ }^{3}$ These reserved powers include admission of new members, approval of revisions to quota (a member's share of financial resources and voting power within the Fund), requiring a member to withdraw from membership, approval of allocation of Special Drawing Rights (SDRs), which is the IMF's unit of account, decision to liquidate the Fund and deciding appeals on interpretation of the Articles of Agreement. The Board of Governors made the delegation to

2 Articles of Agreement, Article XII, Section 2(a) provides that "[A]ll powers under this Agreement not conferred directly on the Board of Governors, the Executive Board, or the Managing Director shall be vested in the Board of Governors."

3 Articles of Agreement, Article XII, Section 2(b) authorizes the Board of Governors to "delegate to the Executive Board authority to exercise any powers of the Board of Governors, except the powers conferred directly by this Agreement on the Board of Governors." 
the Executive Board in the broadest possible terms in 1946 (amended in 1978). ${ }^{4}$ As a result, the bulk of decisions to be taken was shifted from the Board of Governors to the Executive Board.

The Executive Board is responsible for conducting the business of the Fund, ${ }^{5}$ and functions in continuous session. ${ }^{6}$ Its powers consist of those directly conferred upon it by the Articles of Agreement and also those that have been delegated by the Board of Governors. Accordingly, the Executive Board is responsible for taking almost all of the Fund's key decisions. It comprises 24 members who used to be elected or appointed by the Fund's members before the 2010 Fund governance reform. In 2010, the Fund embarked on a farreaching reform of its governance structure by, among other things, creating an all-elected Executive Board. As a result of this reform which became effective in January 2016, all members of the Executive Board are now elected by the Fund's members every two years, strengthening the democracy of the Executive Board governance structure. Executive Directors are officials of the Fund and legally accountable to the Fund for the discharge of their duties.

Decisions taken by the Board of Governors and the Executive Board are based on a weighted voting system. ${ }^{7}$ When a country joins the Fund, it is assigned an initial quota in the same range as the quotas of existing members ${ }^{8}$ of broadly comparable economic size and characteristics. The quota, which is based on the relative size of the member's economy in the world economy, largely determines a member's voting power in Fund decisions. The 2010 reform delivers an unprecedented 100 percent increase in total quotas and a major realignment of quota shares to reflect the changing relative weights of the Fund member countries in the global economy. In particular, it shifted more than six percent of quota shares from over-represented to under-represented member countries and more than six percent of quota shares to dynamic emerging market and developing countries. The reform represents a major step towards better reflecting the increasing role of dynamic emerging market and developing countries in the Fund's governance structure. All decisions of

4 This delegation which is formulated in Section 15 of the Fund's By-Laws reads as follows: "The Executive Board is authorized by the Board of Governors to exercise all the powers of the Board of Governors except those conferred directly by the Articles of Agreement on the Board of Governors."

5 Articles of Agreement, Article XII, Section 3(a).

6 Articles of Agreement, Article XII, Section 3(g).

7 The votes cast by members consists of basic votes and quota based votes (one additional vote for each SDR10o,ooo of quota).

8 http://www.imf.org/external/np/sec/memdir/members.htm. 
the Board of Governors or the Executive Board are made by a majority of the votes cast except as otherwise specifically provided. ${ }^{9}$

Finally, the Managing Director is selected by the Executive Board and performs the powers conferred on him or her by the Articles of Agreement. While there is no delegation of authority as such by the Executive Board to the Managing Director, the Managing Director performs his or her functions under the direction and general control of the Executive Board. The Managing Director conducts the ordinary business of the Fund under the direction of the Executive Board. ${ }^{10} \mathrm{He}$ or she is the chief of the staff and is responsible for the organization, appointment and dismissal of the staff of the Fund subject to the general control of the Executive Board. ${ }^{11}$ The Managing Director and staff, in the discharge of their functions, owe their duty entirely to the Fund and each member of the Fund is required to respect the international character of such duty and refrain from all attempts to influence any of the staff in the discharge of their functions. ${ }^{12}$ In addition, the Managing Director is the Chairman of the Executive Board, where he or she has no vote except to break a deadlock in case of an equal division of votes. ${ }^{13}$

Accordingly, responding to the Fund's governance structure, there are four principal sources of Fund laws. The first source is the Articles of Agreement, the founding charter of the Fund. The Articles of Agreement are an international agreement whose interpretation is governed by the rules on international treaty interpretation. The Charter defines the purposes of the Fund, its core mandate and certain functions that the Fund needs to perform in furtherance of these purposes. The Articles of Agreement also establish certain obligations that members are required to observe. The second source is the Fund's Bylaws and resolutions adopted by the Board of Governors. The third source is rules and regulations, and decisions adopted by the Executive Board. The final source refers to General Administrative Orders and staff guidance notes issued by the Managing Director.

Notwithstanding the above, several powers of the Fund are not conferred specifically to any of the three organs, but rather are conferred upon "the

9 Articles of Agreement, Article XII, Section 5 (c). There are two types of special majorities; $70 \%$ (e.g., a change in the rate of charge under Article v, Section 8(d)) and 85\% (e.g., adoption of a new repurchase period under Article v, Section $7(\mathrm{c})$ and $(\mathrm{d})$ ).

10 Articles of Agreement, Article XII, Section 4(b).

11 Ibid.

12 Articles of Agreement, Article XII, Section 4(c).

13 Articles of Agreement. Article XII, Section 4(a). 
Fund." In general terms, the Fund typically refers to the Executive Board but, given that the Articles do not expressly define "the Fund" or the issue of who can speak for the Fund, a reference to the Fund in a Fund document or communication can have different meanings in different contexts. It would depend on which organ has the power to decide on that particular matter mentioned in the document or communication. For instance, if the statement relates to admission of a new member, the Fund refers to the Board of Governors since admission to Fund membership is a power directly conferred upon the Board of Governors. Similarly, a statement on the appointment of a new Department Director would imply a reference to the Managing Director who is directly conferred with the power to appoint Fund staff.

\section{3}

\section{Fund's Powers}

The Fund's mandate originate in its Articles of Agreement. The overall objective of the Fund to promote international monetary and financial stability remains unchanged since its establishment in 1945. The Articles of Agreement generally confer three types of powers upon the Fund in furtherance of this objective: (i) oversight powers to monitor and promote the observance of members' obligations under the Articles of Agreement; (ii) financing powers to provide financial assistance to members to help them address balance of payments problems; and (iii) advisory powers to provide financial and technical services to members upon request.

\subsection{Oversight Powers}

The oversight powers refer to the Fund's responsibility to promote international financial stability and monetary cooperation, and to exercise oversight over members' compliance with their obligations under the Articles of Agreement. Article IV, Section 3 requires the Fund to conduct both bilateral and multilateral surveillance, which are mutually supportive and reinforcing and provide effective integrated surveillance in a highly-integrated world economy. In conducting such surveillance, the Fund pays due regard to country circumstances, recognizes the importance of continuous dialogue, candor and evenhandedness, and emphasizes the collaborative nature of the exercise.

Article IV of the Articles of Agreement sets forth certain obligations that members are required to observe concerning their exchange rate policies as well as domestic economic and financial sector policies. Under Article IV, members undertake to collaborate with the Fund and other members to assure orderly exchange arrangements and to promote a stable system of exchange 
rates. ${ }^{14}$ Article IV, Section 3 requires the Fund to conduct both bilateral and multilateral surveillance. Recognizing the increasingly important international dimensions of surveillance and of cross-country spillovers, the Fund adopted in 2012 an integrated surveillance decision under Article IV, making consultations a vehicle for both bilateral and multilateral surveillance, to achieve better operational integration of these responsibilities. ${ }^{15}$ This decision helps ensure that these responsibilities are mutually supportive and reinforcing, allowing the Fund to discuss the full range of spillovers from a member's policies that affect global stability.

In its bilateral surveillance with individual member countries, the Fund exercises firm surveillance over members' exchange rate policies under Article IV, Section $3(\mathrm{~b})$ where the Fund assesses whether a member's exchange rate policies are promoting balance of payments stability. ${ }^{16}$ Members are required to avoid manipulating exchange rates or the international monetary system in order to prevent effective balance of payments adjustment or to gain an unfair competitive advantage over other members. The Fund also exercises general oversight over members' domestic and financial policies under Article IV, Section 3(a) where the Fund assesses whether these policies are promoting domestic stability, and advises the member on policy adjustments necessary for these purposes. In this regard, members are required to (i) endeavor to direct their policies toward the objective of fostering orderly economic growth with reasonable price stability, with due regard to their circumstances and (ii) seek to promote stability by fostering orderly underlying economic and financial conditions and a monetary system that does not tend to produce erratic disruptions.

Article IV assumes that if each member adopts policies that promote its own balance of payments stability and domestic stability, it will contribute to an orderly and stable system of exchange rates. In order for the Fund to exercise this oversight power, members are required to provide the information necessary to enable the Fund to conduct surveillance, ${ }^{17}$ and to consult with the Fund regarding these policies when requested by the Fund. ${ }^{18}$ While

14 Articles of Agreement, Article Iv, Section 1. The Fund recognizes that members have legitimate policy objectives including domestic social and political policy objectives that are beyond the scope of Article IV.

15 International Monetary Fund, "Factsheet-Integrated Surveillance Decision" (2013), $<$ http://www.imf.org/external/np/exr/facts/isd.htm> accessed 30 September 2013.

16 Ibid.

17 Article of Agreement, Article IV, Section 3(b).

18 Articles of Agreement, Article IV Section 3(b) with respect to exchange rate policies and Section 1 with respect to domestic policies. 
bilateral surveillance normally takes place annually, the Fund engages in continuous and frank dialogue with its members over their policies. In the context of bilateral surveillance, the Fund's assessment and advice take into account the impact of a member's policies on other members to the extent that the member's policies undermine the promotion of its own balance of payments or domestic stability.

At the multilateral level, Article IV, Section 3(a) requires the Fund to oversee the international monetary system to ensure its effective operation. In the context of multilateral surveillance, the Fund focuses on issues that may affect the effective operation of the international monetary system, including global economic and financial stability, and the spillovers arising from policies of individual members that may significantly influence the effective operation of the international monetary system. While the Fund may not require a member to change its policies in the interest of the effective operation of the international monetary system, members are encouraged to implement their policies that are conducive to achieving this objective. Multilateral surveillance can take several forms. For instance, the Fund has conducted multilateral exercises through analyses and assessments in the World Economic Outlook, the Global Financial Stability Report and the Early Warning Exercise.

\section{2 $\quad$ Financing Powers}

The financing powers refer to the Fund's ability to provide financial assistance to members to help them address balance of payments problems. ${ }^{19}$ The Articles of Agreement require the Fund's financing assistance to meet two requirements. First, it is used to resolve, rather than delay the resolution of, the member's balance of payments problem, and cannot be provided for any other purposes. A member may use the Fund's general resources only to the extent it has a balance of payments need, i.e., a need arising from its balance of payments or its reserve position or developments in its reserves. ${ }^{20}$ The definition of balance of payments need has been sufficiently flexible to enable the Fund to provide financing in a variety of circumstances. Second, the member will be in a position to repay the Fund in accordance with the relevant maturity schedule. ${ }^{21}$ These conditions, while distinct, are related since the resolution of

19 As set out in Articles of Agreement, Article I(v), the purpose of IMF financing is to " $\mathrm{T}] \mathrm{o}$ give confidence to members by making the general resources of the Fund temporarily available to them under adequate safeguards, thus providing them with opportunity to correct maladjustments in their balance of payments without resorting to measures destructive of national or international prosperity."

20 Articles of Agreement, Article v, Section 3(b)(ii).

21 Articles of Agreement, Article V, Section 3(a) provides that "[T] he Fund shall adopt policies on the use of its general resources, including policies on stand-by or similar 
a member's balance of payments problem will enhance its capacity to repay the Fund.

To operationalize these requirements, the Fund extends financing to a member only if the member is prepared to implement a program of economic, financial and structural reform designed to address the underlying balance of payments problem. The member has the primary responsibility for designing the program. If the program is successfully implemented, the member will restore or maintain balance of payments viability and macroeconomic stability, while setting the stage for sustained growth. This will in turn enable the member to repay the Fund. To achieve these objectives, the Fund's financing is disbursed in installments that are linked to conditions. The Fund's Executive Board reviews a member's performance under the member's financing arrangement where the member must show that it has met an economic target or implemented a structural reform in order to receive a disbursement. In respect of program-related structural conditions, a failure to meet such a structural condition would not in itself result in the non-completion of a program review by the Fund's Executive Board. Rather, completion of a program review would require a judgment by the Executive Board that there are compensating factors giving confidence that program objectives are being achieved. This aims to ensure progress in program implementation and to reduce risks to the Fund resources. These conditions are drawn from the member's reform program and vary case by case depending on the member's specific circumstances.

The Fund's policies on conditionality have evolved over the years in response to changing economic circumstances. In the early 1980s, with the Fund's growing involvement in low income and transition countries, the Fund's conditionality expanded from its traditional focus on macroeconomic policies to include structural measures. This reflects the Fund's recognition that severe structural problems ranging from lack of robust legal and institutional frameworks for bank resolution and corporate insolvency to prevalent corruption hindered economic stability and growth in those countries. In recent years, conditionality in the Fund supported programs has become nimbler and better tailored to the specific challenges faced by the member. ${ }^{22}$

arrangements, and may adopt special policies for special balance of payments problems, that will assist members to solve their balance of payments programs in a manner that is consistent with the provisions of this Agreement and that will establish adequate safeguards for the temporary use of the general resources of the Fund."

Conditionality has become more focused on critical structural reforms that are within the Fund's core areas and its design has reflected countries' specific circumstances. For example, for Fund supported programs for fragile states, such countries' vulnerabilities and capacity constraints are taken into consideration in program design. 


\subsection{Advisory Powers}

Article IV, Section 2(b) allows the Fund to perform, upon request, financial and technical services, which are consistent with the Fund's purposes. Technical services generally take the form of the Fund providing technical assistance and training to help member governments put in place or enhance effective institutions, legal frameworks, and policies to promote economic stability and growth. It is open to any Fund member to request these services, and these services are voluntary for both the Fund and the member country, that is, the services are only provided to the member if requested, and the Fund is under no obligation to honor the request. The Fund's technical assistance and training cover a wide array of areas of importance to the Fund, including macroeconomic policy framework and management; balance of payment issues; monetary policy and exchange rate policy; financial stability frameworks; debt and asset liability management; fiscal policy and institutional frameworks; data dissemination standards; and legislative frameworks. Over the years, technical services have been integrated with and informed the policy dialogue between the Fund and its members under surveillance as well as Fund-supported programs. The Fund cooperates closely with other providers of capacity development. Given its focus on core areas of expertise and limited resources, the Fund seeks to avoid duplication in coverage and to enhance complementarity with other capacity development providers.

Legal counsels play a range of different roles at the Fund in assisting the institution in discharging its three powers noted above. Generally speaking, their roles fall into three categories.

First, legal counsels take on a traditional role as the Fund's in-house counselor. They advise the Fund's organs on the "legality" of their decisions. In doing so, they need to ensure that three principles must be observed. First, all decisions are consistent with the Articles of Agreement. Second, all decisions of a subordinate organ must be consistent with higher norms. For instance, the Executive Board must, in the exercise of its delegated authority, comply with the decisions of the Board of Governors. Third, all individual decisions of a Fund organ must be consistent with the general decisions of that organ. The Executive Board adopts both general and individual decisions. It adopts the general decisions to establish, for instance, the general parameters for providing the Fund's financial assistance including the maximum amount of the assistance and program length. It also takes individual decisions to grant 
financial assistance to a member. The Legal Department has advised that such individual decisions must be consistent with the terms and principles of the general decisions given their subordinate nature. Finally, exercise of any discretionary powers by any Fund organ cannot be discriminatory. In this regard, the principle of uniform treatment of all members implied from the Articles of Agreement is regarded as a general principle of the law of the Fund. However, the principle of uniformity of treatment does not require equal treatment of all members, but rather similar treatment of similarly situated members. Adherence to these principles is pertinent to the integrity of the rule of law and central to the credibility and legitimacy of the Fund's decision-making organs.

Legal counsels also advise on whether Fund members' actions are consistent with their obligations under the Articles of Agreement. For instance, when a member introduces a measure, which impacts the operation of its foreign exchange system such as limitations on the allocation of foreign exchange for current payments and transfers or taxes on foreign exchange transactions, legal counsel needs to determine whether such measure imposes restrictions on the making of payments and payments for current international transactions without the approval of the Fund. Finally, legal counsels advise the Fund's organs and membership on interpretation of the Articles of Agreement and the decisions adopted by the Fund's organs and also on the correct application of the rules and policies.

Second, legal counsels act as trusted advisors to member authorities. An increasing number of legal counsels at the Fund are engaged in assisting members in reforming their legal and institutional frameworks. Traditionally, legal technical assistance of the Fund's Legal Department focused on central banking, bank insolvency, and tax and budget legislation. However, events over the past 20 years and in particular the Asian crisis and the global financial crisis have underscored the important role that the law plays in contributing to financial stability and integrity at the global, regional and national levels. The Fund's Legal Department has expanded its legal technical assistance into new areas and is actively involved in strengthening financial sector legal frameworks.

For instance, large bank failures during the global financial crisis brought home the lack of adequate tools to resolve "too-big-to-fail" institutions, and misaligned incentives and lack of robust mechanisms for cross-border bank resolution and cooperation. This left some country authorities with little choice but to take unilateral actions, which contributed to the high fiscal costs of the crisis and resulted in disorderly resolution in some cases. Developing an effective framework for cross-border resolution is a key priority in the global regulatory reform. The Fund's Legal Department contributed to the establishment of an international standard for the resolution of systemically important 
banks, the Key Attributes of Effective Resolution Regimes for Financial Institutions ("Key Attributes"), ${ }^{23}$ in close collaboration with the Financial Stability Board. These Key Attributes call for countries to put in place resolution regimes that give the authorities comprehensive resolution powers while establishing effective mechanisms for cross-border cooperation and for the allocation of losses to private stakeholders. Legal counsels have been assisting members in strengthening their resolution and crisis management frameworks in line with the best practices envisaged in the Key Attributes.

Many countries are paying increasing attention to the magnitude and macroeconomic implications of corporate debt overhang. ${ }^{24}$ High repayment burdens reduce the ability of enterprises to invest, while also reducing banks' willingness to lend. High levels of corporate over-indebtedness can quickly translate into high levels of non-performing loans. As a result, bank capital that could be used to support fresh lending is locked up, and thus credit supply by financial institutions is limited. Banks often try to "evergreen" their loans to over-indebted businesses hoping that the situation will improve, which can contribute to the misallocation of financing and maintaining "zombie" companies. The lack of credit exacerbates the distress of corporates and this reinforces the negative loop by increasing loan defaults. Rising nonperforming loans, falling collateral values, and higher borrowing costs can quickly erode banks' capital buffers and have systemic consequences for the banking sector, and threaten financial stability. Building on its experience during the Asian crisis, the Legal Department has been assisting member countries including Italy, India and Mongolia in developing a comprehensive strategy to tackle corporate over-indebtedness and in designing and implementing reform measures including enhancing debt enforcement regimes, strengthening corporate insolvency systems, developing an out of court restructuring mechanism, removing tax disincentives to support debt restructuring, improving prudential regulation and supervision, and strengthening the capacity and integrity of the institutional framework.

A final example relates to anti-money laundering and combating the financing of terrorism (AML/CFT) which now accounts for a lion's share of technical assistance of the Fund's Legal Department. The Fund's involvement in AML/CFT dates back to the early 2000 s in response to calls from the

23 <http://www.fsb.org/what-we-do/policy-development/effective-resolution-regimes-andpolicies/key-attributes-of-effective-resolution-regimes-for-financial-institutions>

24 For instance, debt overhangs are holding back economic recovery in several euro area countries as the financial crisis and ensuing recessions have left many European countries with large debt overhangs and with high levels of non-performing loans. 
international community due to concerns that money laundering and terrorist financing can threaten the stability of a country's financial sector or its external stability more generally. A robust AML/CFT regime helps enhance the integrity and stability of financial sectors, which in turn helps countries become integrated into the global financial system and strengthen governance and tax administration. Over the past 17 years, the Fund has helped shape international and national AML/CFT policies and supported member countries in building defenses against money laundering and terrorist financing. The Legal Department which now undertakes all Fund's work in this area has been involved in more than 120 assessments of members' compliance with the international AML/CFT standard and established an extensive capacity building program to help member countries strengthen their AML/CFT frameworks. In 2009, the Fund launched a donor supported trust fund to finance AML/CFT capacity development in its member countries. ${ }^{25}$ The Legal Department has provided technical assistance on AML/CFT to more than 120 countries.

Finally, legal counsels at the Fund are public policy contributors. They are often called upon to provide policy advice, in addition to legal advice, and are directly involved in the development of Fund policies. There are several reasons for this role. First, given their involvement in assessing legality of all policies in the Fund, they are uniquely placed to bring an institutional perspective and memory to bear on these policy discussions and debates. Second, legal counsels need to help management think through the potential impact and implications of the proposal and ensure that all possible impacts and consequences of the policy have been anticipated. This would help legal counsels to formulate the policy clearly and correctly in a legally binding decision. Moreover, legal counsels seek to find practical solutions which are consistent with the Articles of Agreement, rules and regulations, decisions by the Executive Board while at the same time achieving the intended policy objectives. The Fund has developed the practice of having legal counsels on board in the early stages of policy development. Three examples illustrate the broad array of areas where legal counsels are contributing to policy development.

The Legal Department plays a lead role in the Fund's work on withdrawal of correspondent banking relationships (С ВRs). Correspondent banking relationship involves a correspondent bank providing a deposit account or other liability account and a range of services to a respondent bank and its customers and requires an exchange of messages between banks to settle transactions by crediting or debiting accounts. This work stream is in response to the membership's

25 IMF, Topical Trust Funds Aim to Expand IMF's Capacity Building, <http://www.imf.org/ external/np/exr/key/ttf.htm> 
concerns over pullback by global banks from correspondent banking in certain pockets of the world. In today's highly interconnected economic world, correspondent banking plays an important role in supporting economic growth and promoting financial inclusion. Withdrawal of свRs could accentuate financial fragilities in some countries, and undermine their growth, development and financial inclusion prospects by increasing costs of financial services. The Fund has been focusing on identifying drivers leading to СвR withdrawals, analyzing and monitoring risks, and providing advice on how to tackle CBR challenges. ${ }^{26}$ Legal counsels are deeply involved in examining the factors behind this phenomenon which go beyond legal issues. In this regard, their work recognizes that СвR withdrawals reflect individual banks' business decisions based on an assessment of the profitability and risks of СвRs, and indicates that these decisions have been shaped by the recent changes in the regulatory, supervisory and enforcement landscape, notably with respect to more rigorous prudential requirements, and enhanced implementation and enforcement of the AML/CFT standards (in particular "know your customer" requirements), and economic and trade sanctions. Given the multitude of drivers, there is no one-size-fits-all solution, and responses need to be tailored to the country circumstances. The Fund has been facilitating candid and constructive dialogue among public and private sector stakeholders to identify concrete solutions to help countries address СвR pressures. In this regard, the Legal Department played a key role in the design and implementation of the Caribbean Initiative launched in February 2017, a regional approach that brings global and respondent banks together to develop actionable and practical measures to tackle С BRs problems in the Caribbean. ${ }^{27}$ Similar regional initiatives will be launched in the Pacific and Africa in 2018.

Recent years witness the quick evolution of digital technology which is transforming the financial services industry, creating both opportunities and challenges for consumers, service providers and regulators. So-called FinTech that leverages technology enabled innovation such as big data, artificial intelligence, and cryptography offer the promise of providing financial services more quickly and at a lower cost. The widespread adoption of technologies bodes well for financial inclusion but presents challenges for regulation and

26 International Monetary Fund, "The Withdrawal of Correspondent Banking Relationships: A Case for Policy Action" (2016) sDN/16/o6, <https://www.imf.org/external/pubs/ $\mathrm{ft} / \mathrm{sdn} / 2016 / \mathrm{sdn} 1606 . p d f>$ accessed 30 June 2016. International Monetary Fund, "Recent Trends in Correspondent Banking Relationships-Further Considerations" (2017) $<$ https://www.imf.org/ /media/Files/Publications/PP/o31617.ashx> accessed 21 April 2017. 
supervision. Developments in FinTech raise important questions that are not only national but also global in scale. Given its mandate to promote a stable international monetary system, the Fund has been closely monitoring the development of FinTech with a focus on the impact of this new wave of innovative technologies on cross border payments. ${ }^{28}$ The Legal Department has been actively involved in examining how the law can contribute to the efforts to strike the right balance between addressing the risks associated with the development of the new FinTech industry, while avoiding overregulation that could stifle innovation. Its work points to the need for regulatory authorities to ensure that trust is maintained in an evolving financial system. In particular, regulators may need to complement their focus on entities with increasing attention to activities. Since financial services are increasingly provided by a diverse group of firms and market platforms, governance needs to be strengthened to ensure the integrity of data, algorithms and platforms. Finally, legal principles need to be modernized to clarify rights and obligations under the new global financial landscape.

\section{Independence, Consistency and Continuity}

Across these roles, legal counsels at the Fund provide legal advice to multiple parties at the Fund: the Board of Governors, the Executive Board, Fund management and other Fund departments. With such diverse recipients, it is paramount for legal counsels to maintain credibility and effectiveness of their legal advice, which helps ensure the rule of law at the Fund. To achieve this, they are guided by four key principles.

The first and foremost principle relates to independence and objectivity of legal counsels. Their responsibility is to provide objective, impartial and consistent advice based on a thorough and well-founded legal analysis of the Articles of Agreement, rules and regulations, and decisions by the Fund decision making organs. They are not advocates of any Fund organ or member, and their relationship is with the law, not the institution. This is particularly important given that there is no provision in the Fund's Articles of Agreement for judicial review of a decision of a Fund organ. The Fund does not have an independent

28 International Monetary Fund, "Virtual Currencies and Beyond: Initial Considerations" (2016) <https://www.imf.org/external/pubs/ft/sdn/2016/sdn16o3.pdf> accessed 20 January 2016. International Monetary Fund, "Fintech and Financial Services: Initial Considerations" (2017) SDN/17/05, <https://www.imf.org/ /media/Files/Publications/SDN/2017/ sdn1705.ashx > accessed 16June 2017. 
dispute resolution process, except in the administrative law area. ${ }^{29}$ However, a member may request a formal interpretation of the Articles of Agreement. ${ }^{30}$ Such request will be put to the Executive Board, with an appeal to the Board of Governors whose decision is final. ${ }^{31}$ Therefore, the Fund is the sole judge of whether a decision taken by one of its organs is consistent with the Articles of Agreement. This power is strengthened by its immunity from judicial process. $^{32}$ This procedure was only used 10 times in the early days of the Fund, and it has not been used since then.

Experience has shown that the Fund can operate properly without any mandatory form of judicial review of the Fund's decisions. The absence of judicial review has not been viewed by the Fund as an exemption from the rule of law. Instead, the Fund has always recognized the importance of abiding by its charter, rules and regulations. In this regard, legal counsels are regularly called upon to provide advice on the legality of a decision by a Fund organ. The Fund organs have been sufficiently sensitive to legal concerns and receptive to legal advice. In practice, they normally involve legal counsels in the early stages of policy development to ensure the legality of the decision and rely on their advice for the resolution of legal issues. To the extent that a reform proposal, while making sense from a policy perspective, could not be introduced through interpretation of the Articles of Agreement, legal counsels have been advising on the need to amend the Articles. Amendments of the Articles requires a proposal of the Board of Governors and approval by three fifths of the

29 The Fund has in place two levels of review for the formal channels of resolution of employment disputes between the Fund and its staff. The first level of review is conducted by the Grievance Committee, a three-person committee established in 1980 which is headed by a professional arbitrator or lawyers appointed by the Managing Director, and composed of one staff appointee from the Staff Association, and another appointed by Fund management. The committee makes recommendations to the Managing Director on challenges brought by staff to a decision of the Fund. The second level of review is conducted by the IMF Administrative Tribunal established by the Board of Governors in 1994 and composed of five members. The tribunal is an independent judicial body and its decisions are final and binding on the Fund and the staff member.

30 Articles of Agreement, Article $\operatorname{xxIx}(\mathrm{a})$ reads as follows: "Any question of interpretation of the provisions of this Agreement arising between any member and the Fund or between any members of the Fund shall be submitted to the Executive for its decision."

31 Articles of Agreement, Article XXIX (b). Any question referred to the Board of Governors shall be considered by a Committee on Interpretation of the Board of Governors. The Board of Governors shall establish the membership, procedures and voting majorities of the Committee. A decision of the Committee shall be the decision of the Board of Governors unless the Board of Governors, by $85 \%$ majority of the total voting power, decision otherwise.

Articles of Agreement, Article IX, Section 3. 
member countries having 85 percent of the total voting power. ${ }^{33}$ The Articles of Agreement have been amended seven times, evidencing the Fund's acceptance that there are limitations to the adoption of reforms through interpretation of the charter. Independence and objectivity of legal counsels at the Fund is pivotal to the legitimacy of the Fund's decisions. If legal counsels are perceived to be an advocate of a Fund organ or a member, it would undermine the credibility of their role. Finally, legal counsels strive to maintain consistency of legal advice to provide predictability, contributing to credibility and ensuring uniform treatment of its members.

The second principle is that legal counsels are to perform the functions of not only compliance officers but also problem solvers. Legal counsels need to ensure consistency of the decisions of the Fund's organs with the Articles of Agreement, rules and regulations as well as correct application of those policies. If a policy proposal is found to be inconsistent, their responsibility does not end with such an assessment. Rather they need to find ways to modify the proposal so that it can be accommodated under the existing legal framework, while still achieving the intended objectives. Providing legal advice in a balanced and accurate manner requires legal counsels to understand the policy rationale behind the decision, the objectives it is intended to achieve, and how it has been applied since its adoption. Legal counsels also need to appreciate the nuances of the decision-making process, while being proactive and innovative.

The third principle concerns the need to distinguish legal advice from policy advice. As noted above, legal counsels are often called upon to provide both legal and policy advice. It is critical that they understand where the line is between these two, since mixing legal and policy issues could undermine the clarity and credibility of their legal advice. On legal issues, legal counsels must take full and exclusive responsibility. However, on policy issues, their views are just one of the voices in the policy debate. The line between these two is not always clear, and whether an issue is a legal or policy one must be determined by legal counsels. It is also important that they clearly communicate such determination to the Fund's organs and departments so that there is a shared understanding of the line between legal and policy advice.

The final principle concerns communication. It is critical that legal counsels can explain their advice clearly and effectively to the Board of Governors, the Executive Board, management, colleagues in other departments, and member countries. They need to walk them through the legal analysis that provides the 
basis for their advice in a clear way, and not using legal jargons. This would help them understand and accept legal advice.

In addition to these principles, continuity is crucial to the effectiveness of the Legal Department as a whole. Experience shows that continuity enables the department to maintain an institutional memory and perspective which in turn allows legal counsels to advise on policy consistency and coherence. The Legal Department at the Fund has benefited from considerable continuity. First, legal counsels at the Fund tend to stay in the Legal Department. Second, there have only been six General Counsels over the past 70 years.

\section{Conclusion}

While the Fund's mandate to maintain a stable international monetary system has remained constant since 1945, the Fund has evolved considerably to adapt to changes in the global economy. The role of the Fund's Legal Department has changed and grown significantly along with the Fund's evolution. Over the past 20 years, legal counsels' responsibilities have diversified ranging from traditional in-house counselors, trusted advisors to members to active public policy contributors. They have been playing an important role in ensuring that the Fund effectively responds to the changing developments in the international monetary and financial systems while maintaining the rule of law. In this regard, independence, consistency and continuity of the Legal Department is critical to the effectiveness of Fund as an institution. As the Fund will continue to change to meet new challenges in the international monetary system, the rule of law will remain the cornerstone in ensuring the legitimacy and credibility of the Fund to safeguard the international financial architecture. 